\title{
Development of a way to recycle waste glasses: preparation of porous materials from cathode-ray-tubes and/or packaging glasses at the end of their life time
}

\author{
M. Cambon \& B. Liautard \\ Technological Team of Research ERT 3, \\ Laboratoire de Physico-chimie de la Matière Condensée, \\ Montpellier II University, France
}

\begin{abstract}
French and European legislation concerning waste requires studies to be performed on the recycling of products issued from commercial electronic devices. Cathode ray tubes (CRT), and in particular glasses which constitute them, are of major interest. The chemical composition of these glasses is very important. Screen glass is composed of $8-12 \mathrm{wt} \% \mathrm{BaO}$ and $6-10 \mathrm{wt} \% \mathrm{SrO}$ and the cone glass which has a lower wall thickness than that of the screen contains $19-23 \% \mathrm{PbO}$. Previous characterizations of these special glasses led us to propose a way of recycling in which used CRT glass could be treated in order to respond to the legislation. Foam glass could be a possible solution to convert CRT glass into a material with very promising properties. A systematic study of the process parameters showed the possibility of modifying the properties of the porous material. The density can vary from 0.4 to $0.8 \mathrm{~g} . \mathrm{cm}^{-3}$ and the mechanical stress with a uniaxial compressive loading from 20 to $60 \mathrm{MPa}$. The materials have good insulation properties: thermal conductivity $\mathrm{K}$ inferior to $0.25 \mathrm{Wm}^{-1} \mathrm{~K}^{-1}$ and $\varepsilon_{\mathrm{r}}$ between 2.1 and 3.1 at $25^{\circ} \mathrm{C}$. They are non-combustible (like the bulk glass), they resist corrosion in any environment and they present a low thermal expansion coefficient.

Keywords: cathode ray tube glass, recycling, cellular materials, microstructure, porosity, mechanical properties, electrical and thermal conductivity.
\end{abstract}




\section{Introduction}

A cathode ray tube (CRT) typically represents $42 \%$ of the TV or monitor weight. CRTs may contain high levels of lead oxide and other undesirable metal oxides $[1,2]$. At the end of their life time, when they are broken, CRTs can release lead into the environment thus making them a harmful material [3]. While CRT glass may be disposed of in hazardous waste landfills, recycling is the preferred management option for end-of-life CRTs $[4,5]$.

\section{Composition of CRTs}

A CRT is composed of two different types of glass. One, used for the cone section, is characterized by high levels of lead oxide and the other, used for the screen, is typically a lead-free glass that contains high levels of barium oxide [6]. Previous characterizations of waste CRT glasses have been reported. Chemical compositions and physical and chemical properties (the density, $\rho$, the thermal expansion coefficient, $\alpha$ and glass transition temperature, $\mathrm{Tg}$ ) have been determined for each glass. There is a variation in the composition between glass made by different manufacturers, but, we showed surprisingly, that the values of parameters like $\rho, \alpha$ and Tg do not vary significantly for various glass samples, as shown in table 1 . The results indicated that the recycling process can be carried out without taking the origins of each CRT into account $[7,8]$.

Table 1: $\quad$ Properties of bulk glasses.

\begin{tabular}{|c|c|c|c|}
\hline Characteristics & $\begin{array}{c}\text { Color screen CRT } \\
\text { glass }\end{array}$ & $\begin{array}{c}\text { Color cone } \\
\text { CRT glass }\end{array}$ & $\begin{array}{c}\text { Black \& white } \\
\text { CRT glass }\end{array}$ \\
\hline$\rho\left[\right.$ g.cm $\left.{ }^{-3}\right]$ & 2.80 & 3.0 & 2.70 \\
\hline$\alpha_{150-350^{\circ}[}\left[10^{-6} \mathrm{~K}^{-1}\right]$ & 10.5 & 10.5 & 10.5 \\
\hline $\operatorname{Tg}\left[{ }^{\circ} \mathrm{C}^{-1}\right]$ & 520 & 480 & 470 \\
\hline
\end{tabular}

\section{Experimental procedure}

The CRT market overview summarizes several current recycling options as well as future market opportunities, including closed [9] and open-loop recycling [10].

In our study, an open loop recycling process is chosen: recycling waste glass into an expanded glass, a useful product with excellent mechanical and insulation properties [11].

\subsection{Processing}

Various mixtures of glass powders, consisting of cone, screen or a 2:1 ratio of screen to cone glass by weight, were prepared with reducing agents ( $\mathrm{SiC}$ or $\mathrm{TiN}$ ). After the heat treatment of disc shapes obtained by the uniaxial dry pressing of these mixtures, expanded products were obtained in pebble form. 
Samples prepared using different processing conditions, as shown in table 2, were characterized. The influence of the processing parameters on foam glass microstructure and consequently on its physical and chemical properties is studied.

Table 2: $\quad$ Sample compositions and amount of reducing agent.

\begin{tabular}{|c|c|c|}
\hline Sample & Glass & Reducing agent \\
\hline S1 & Cone & $5 \mathrm{wt} \% \mathrm{SiC}$ \\
\hline S2 & $1 / 3$ cone $-2 / 3$ sreen & $5 \mathrm{wt} \% \mathrm{SiC}$ \\
\hline $\mathrm{T} 1$ & Cone & $4 \mathrm{wt} \% \mathrm{TiN}$ \\
\hline $\mathrm{T} 2$ & $1 / 3$ cone $-2 / 3$ screen & $4 \mathrm{wt} \% \mathrm{TiN}$ \\
\hline
\end{tabular}

\subsection{Results and discussion}

The samples were characterized by measuring density with helium pycnometry. The microstructures were examined with scanning electron microscopy. Moreover, in order to valorize foamed glass technology, insulation and mechanical properties of our samples were determined by laser flash experiments, by impedance spectrometry and by compression testing.

\subsubsection{Density-porosity}

Helium pycnometry is a technique to measure the true density of solids. This technique is suitable for measuring the density of porous solids [12].

Since helium, which can enter even the smallest voids of pores, is used to measure the volume per unit weight, the final result gives information about the total porosity:

$$
\% \text { Porosity }=\left(1-\frac{\text { bulk density }}{\text { powder density }}\right) \times 100
$$

Samples were characterized with helium pycnometry using a Micromeritics AccuPyc 1330. Open and closed porosities were obtained with mercury porosimetry using a Micromeritics Autopore II 9220 instrument.

Table 3: $\quad$ Densities and porosities.

\begin{tabular}{|c|c|c|c|c|c|}
\hline Sample & Composition & $\mathrm{T}\left({ }^{\circ} \mathrm{C}\right)$ & $\mathrm{t}(\mathrm{min})$ & $\begin{array}{c}\text { Density } \\
\left(\mathrm{kg} \mathrm{m}^{-3}\right)\end{array}$ & $\begin{array}{c}\text { Porosity } \\
(\%)\end{array}$ \\
\hline SA & $\mathrm{S} 1$ & 750 & 120 & 460 & 84.5 \\
\hline SB & $\mathrm{S} 2$ & 850 & 60 & 375 & 79.5 \\
\hline TA & $\mathrm{T} 1$ & 750 & 120 & 378 & 86.1 \\
\hline TB & $\mathrm{T} 2$ & 850 & 60 & 499 & 78.0 \\
\hline TC & $\mathrm{T} 2$ & 750 & 120 & 878 & 67.9 \\
\hline
\end{tabular}

Results presented in table 3 show that porosity depends on the reaction processes (temperature and time effects) that occur during expansion. Higher porosities are obtained with samples obtained from cone only. This phenomenon 
is due to the composition of CRT glasses: the lead oxide seems to further the expansion process. Reducing agents act preferentially on the lead oxide components of glasses and consequently a gaseous phase $\left(\mathrm{CO}_{2}\right.$ or $\left.\mathrm{N}_{2}\right)$ is obtained yielding foam glasses [13]. Low density samples $\left(\rho=0.375 \mathrm{~g} \mathrm{~cm}^{-3}\right)$ can be prepared with controlled process parameters.

\subsubsection{Microstructural characterization}

Microstructure plays an important role on a wide variety of behavior (mechanical, thermal, electrical, etc.). Microstructure is largely developed during processing $[14,15]$.

Sample morphology was determined with a scanning electron microscope (SEM HITACHI S4500). The SEM microstrucure of samples containing 4 or 5 wt. $\%$ of pore-forming agents are shown in fig. 1 and fig. 2.

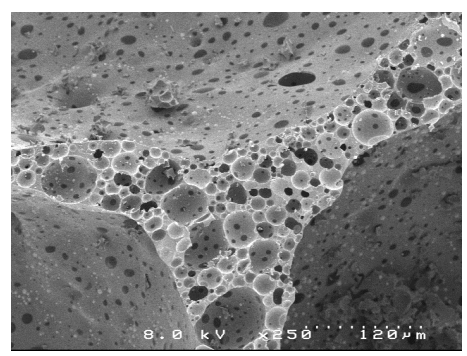

Figure 1: $\quad$ Electron micrograph of a foam glass sample prepared with $4 \mathrm{wt} . \%$ TiN with a magnification of $\times 250$.

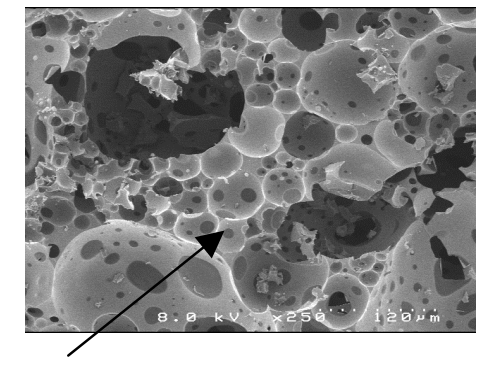

\section{Connecting channels}

Figure 2: $\quad$ Electron micrograph of a foam glass sample prepared with $5 \mathrm{wt} . \%$ $\mathrm{SiC}$ with a magnification of $\times 250$.

It was shown that large pores can be formed. A heterogeneity of the pore size distribution was observed particularly in the case where the reducing agent TiN is used (double distribution of heterogeneity). Generally, the emitted gas $\left(\mathrm{CO}_{2}\right.$ or $\mathrm{N}_{2}$ ) created pores in expanded samples: an increase in the amount of reducing agent produced an increase in the diameters of the pores (up to $300 \mu \mathrm{m}$ ). These pores are interconnected in both samples: smaller dark zones on the micrographs 
were identified as channels connecting the cells [16]. In a previous paper [13], this observation was able to provide an explanation for the difference between the observed pore sizes and the pore size distribution obtained by mercury porosimetry.

\subsubsection{Thermal conductivity}

The laser method was used to determine the thermal conductivities of the samples at room temperature.

In the laser flash method, one surface $($ at $\mathrm{x}=0$ ) of a small disc shaped sample (10 $\mathrm{mm}$ diameter) of $\mathrm{L}=2 \mathrm{~mm}$ thickness is irradiated by a laser pulse $(0.5 \mathrm{~ms})$ and resulting temperature rise at opposite surface $(x=L)$ is used to calculate the thermal diffusivity $\alpha$ of the sample material. Thermal conductivity may be calculated from measurements of thermal diffusivity, specific heat and bulk density. This method is relatively fast and requires a small amount of material. The relationship between lambda (thermal conductivity) and alpha is given by:

$$
\lambda=\alpha \cdot C_{P} \cdot d
$$

where $C_{P}$ is the specific heat measured using a differential scanning calorimeter (Netzsch DSC 200) and d the density.

The results for the thermal conductivity are shown in table 4 and the variation of the thermal conductivity with porosity is shown in fig. 3. The thermal conductivity increases with decreasing porosity. This linear decrease is very interesting; whatever mixtures of glass powders you take, a controlled porosity, i.e. a controlled processing, directly yields the thermal conductivity of the expanded materials. Samples with conductivity values lower than $0.25 \mathrm{Wm}^{-1} \mathrm{~K}^{-1}$ are classified as insulating materials. All our foam glasses can be considered as insulating materials.

Table 4: $\quad$ Thermal conductivities obtained from the laser flash method.

\begin{tabular}{|c|c|c|c|}
\hline Sample & $\mathrm{C}_{\mathrm{P}}\left(\mathrm{J} \mathrm{kg}^{-1} \mathrm{~K}^{-1}\right)$ & $\alpha\left(\mathrm{m}^{2} \mathrm{~s}^{-1}\right)$ & $\mathrm{K}\left(\mathrm{W} \mathrm{m}^{-1} \mathrm{~K}^{-1}\right)$ \\
\hline SA & 800 & $4.73 \times 10^{-7}$ & 0.10 \\
\hline SB & 800 & $4.74 \times 10^{-7}$ & 0.14 \\
\hline TA & 800 & $4.73 \times 10^{-7}$ & 0.08 \\
\hline TB & 800 & $4.74 \times 10^{-7}$ & 0.19 \\
\hline TC & 800 & $4.75 \times 10^{-7}$ & 0.24 \\
\hline
\end{tabular}

\subsubsection{Electrical properties}

In order to fully characterize the electrical properties of a sample, the impedance response must be measured over a wide range of frequencies so that the entire distribution of relaxation times can be captured. Impedance properties were measured using a dielectric spectrometer (Novocontrol BDS 4000) in the frequency range from $0.01 \mathrm{~Hz}$ to $1 \mathrm{MHz}$ at room temperature. The values of bulk resistance, and electrode dimensions, were used to calculate the dc conductivity, $\sigma_{\mathrm{dc}}$, for all foam glasses. The permittivity of samples appears to tend towards a limiting value (from 2.1 to $3.1 \mathrm{~F} \mathrm{~m}^{-1}$ with increasing thickness of material) determined by the porosity (air/vitreous matrix ratio) [17]. In the case of 
electrical properties, the pore diameter has a negligible effect on the permittivity of expanded samples.

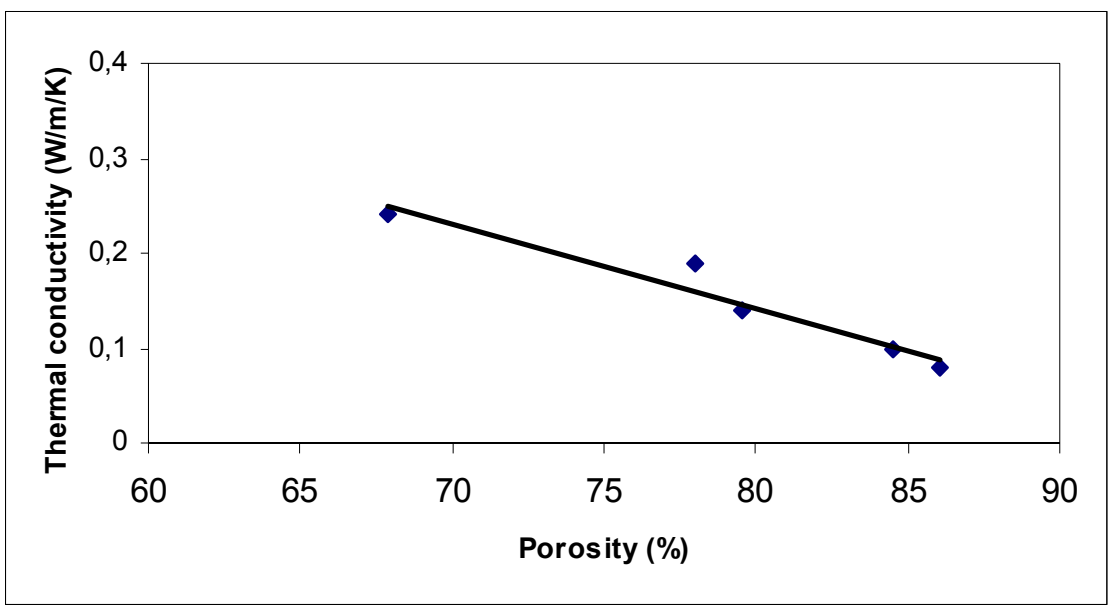

Figure 3: Thermal conductivity as a function of porosity for various samples.

\subsubsection{Compression testing}

Square foam glass samples of $12.5 \mathrm{~mm}$ length and $5 \mathrm{~mm} \times 5 \mathrm{~mm}$ section area were subjected to uniaxial compressive loading. All porous specimens showed similar characteristic compressive behavior during load application [18].

Compression test data results are summarized in table 5. In order to show that there is a compromise between mechanical properties and the porosity level, samples with lower porosities were prepared (only from screen glasses for example). Thus, compressive strengths were plotted as a function of porosity (fig. 4). According to Weibull statistics [8], the maximum bending stress level is $60 \mathrm{MPa}$ for samples with $40 \%$ porosity. Some foam glasses have microstructural heterogeneities, which lead to a reduction in their mechanical performance. The curve indicates that the ultimate strength of the material is a power law function of porosity.

Table 5: $\quad$ Results of the failure stress obtained from the compression tests.

\begin{tabular}{|c|c|c|c|}
\hline Sample & Porosity (\%) & $\sigma(\mathrm{Mpa})$ & $\mathrm{K}(\mathrm{Gpa})$ \\
\hline SA & $84.5(1.7)$ & 4 & $5.4(0.1)$ \\
\hline TA & $86.1(1.7)$ & 4 & $0.4(0.1)$ \\
\hline TC & $67.9(1.4)$ & 24 & $1.9(0.2)$ \\
\hline Screen + SiC : SC & $3.7(0.1)$ & $267(17)$ & $5.4(0.1)$ \\
\hline Mixed + SiC : SD & $46.5(0.9)$ & 60 & $4.4(1.0)$ \\
\hline Screen + TiN : TD & $50.1(1.0)$ & $99(11)$ & $4.7(0.8)$ \\
\hline
\end{tabular}




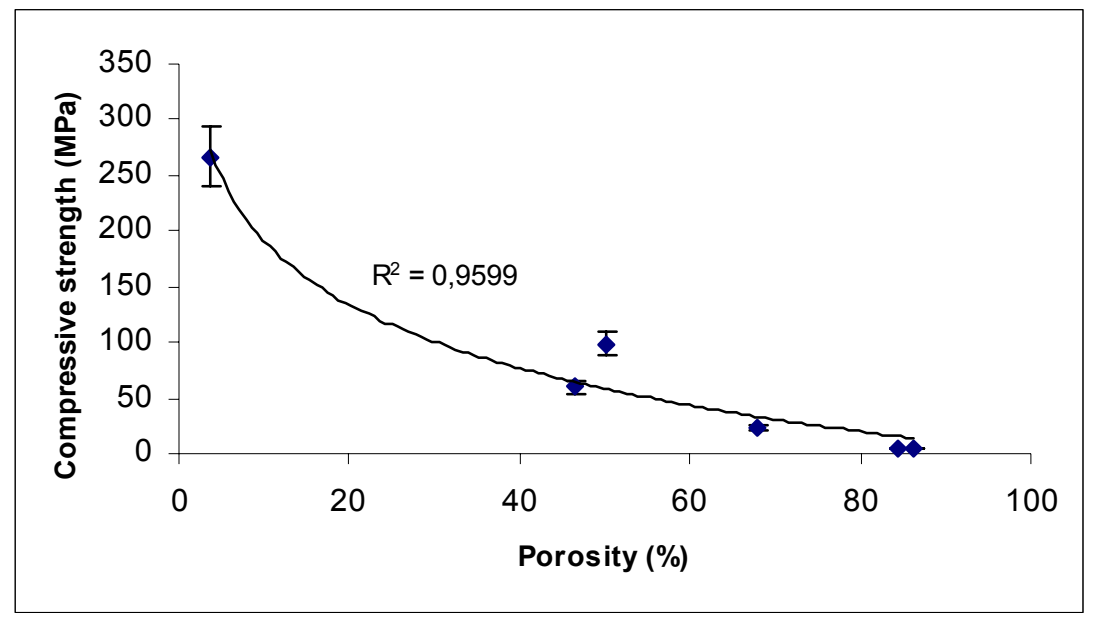

Figure 4: Compressive strength as a function of porosity for various samples.

\section{Conclusion}

The objective of this work was to implement a way to recycle glasses issued from CRT glasses. We showed that the process used to obtain expanded glasses from this raw material source is controlled. We demonstrated that the process parameters (temperature, time, amount of reducing agent and its nature) could modify the properties of the porous material. These parameters modify the microstructure of the expanded product and consequently its physical properties like thermal, electrical and mechanical properties.

We must find a compromise between elaboration process and expected properties. In fact, we show that this material is totally in keeping with the general pattern of waste management. It can find applications in civil engineering and in insulation (sound proofing, thermal, electrical, etc.). The failure mechanisms of strength tested foams can also be studied with a view to manufacture of ultra-lightweight structures such as sandwich panels for example.

\section{References}

[1] Palm, V., Environmental hazards connected to the compositions of cathode-ray tubes and cabinets, In: Report Swedish Environmental Research Institute, Stockholm, Sweden, 1995.

[2] Andreola, F., Barbieri, L., Corradi, A., Lancellotti, I., Falcone, R., Hreglich, S., Glass-ceramics obtained by the recycling of end of life cathode ray tubes glass. Waste Manage, 25, pp. 183-189, 2005.

[3] Musson, E., Yong-Chul, J., Tonwsend, T.G., Il-Hyun, C., Characterization of lead leachability from cathode-ray-tubes using the toxicity 
characteristic leaching procedure. Environ. Sci. Technol., 34, pp. 43764381, 2000.

[4] Smith, A.S., Recycled CRT panel glass as an energy reducing fluxing body additive in heavy clay construction products, In: Creating Markets for Recycled Resources, Waste and Resource Action Programme (WRAP), Oxon, United Kingdom, 2004.

[5] Turmel, J.M., Rocherulle, J., Grange, P., Razafindrakoto, J., Verdier, P., Laurent, Y., European Patent 0871520, 1998.

[6] Méar, F., Yot, P., Cambon, M., Ribes, M., The characterization of waste cathode-ray tube glass, Waste Management, (in press), 2006.

[7] Méar, F., Yot, P., Cambon, M., Liautard, B., Cathode ray tube (CRT) glasses valorization. Part 1: characterization of the deposit, Verre Review, 9 (1), pp. 33-41, 2003.

[8] Méar, F., Yot, P., Cambon, M., Ribes, M., Properties and structural characterization of foam glass elaborated from cathode ray tube. Advances in Applied Ceramics, 104 (3), 2005.

[9] Piers, J., Peelen, J., US Patent 5725627, 1998.

[10] Garnier, C., Verdier, P., Razafindrakoto, J., Laurent, Y., WO Patent 9831639, 1998.

[11] Cambon, M., Yot, P., Méar, F., Liautard, B., Foam glass: a very promising way of valorization for cathode ray tubes. Proc. of the $19^{\text {th }}$ International Conference on Solid Waste Technology and Management, Philadelphia PA, USA, pp. 1097-1106, 2004.

[12] Méar, F., Yot, P., Cambon, M., Caplain, R., Ribes, M., Characterisation of porous glasses prepared from Cathode Ray Tube (CRT), Powder Technology, 162, pp. 59-63, 2006.

[13] Méar, F., Yot, P., Cambon, M., Ribes, M., The changes in lead silicate glasses induced by the addition of a reducing agent (TiN or SiC), Journal of non-crystalline solids, 351, pp. 3314-3319, 2005.

[14] Cot, L., Ayral, A., Durand, J., Guizard, C., Hovnanian, N., Julbe, J., Larbot, A., Inorganic membranes and solid state sciences, Solid State Sciences, 2, pp. 313-334, 2000.

[15] SanMarchi, C., Mortensen, A., Deformation of open-cell aluminium foam, Acta Materialia, 49, pp. 3959-3969, 2001.

[16] Desforges, A., Arpontet, M., Deleuze, H., Mondain-Monval, O., Synthesis and functionalisation of polyHIPE beads, Reactive and Functional Polymers, 53 (1), p. 241, 2004.

[17] Bansal, N.P., Zhu, D., Thermal conductivity of zirconia-alumina composites, Ceramics International, 31 (7), pp. 911-916, 2005.

[18] Tasserie, M., Ph. D. thesis, Rennes University, France, 1991. 